\title{
The Importance of Size in Private Equity: Evidence from a Survey of Limited Partners
}

\author{
Marco Da Rin* and Ludovic Phalippou**
}

July 2016

\section{Forthcoming, Journal of Financial Intermediation}

\begin{abstract}
Using a comprehensive survey, we show that investors with a larger capital allocation to private equity are more specialized - measured by the degree to which the investor focuses on private equity rather than other classes of investments - and have a wider scope of due diligence and investment activities. Other investor characteristics (experience, type, location, compensation structure, number of funds under management) play no role. In particular, Endowments are not special according to the survey measures. These results are consistent with the changing LP-GP relationship in private equity as capital is increasingly concentrated in the hands of large investors.
\end{abstract}

Keywords: Institutional Investors; Limited Partners; Investor Heterogeneity; Due Diligence; Private Equity.

JEL Codes G20, G22, G23, G24.

*Tilburg University, Department of Finance, Warandelaan 2, 5037AB, Tilburg, The Netherlands; marco.darin@uvt.nl - corresponding author

**University of Oxford, Said Business School and Oxford-Man Institute of Quantitative Finance.

Ludovic.Phalippou@sbs.ox.ac.uk

We are grateful to the many investors who provided us with the data. This paper previously circulated under the title 'There is something special about large investors.' We especially thank James Bachman and Peter Cornelius for their help in designing the survey. We also thank an anonymous referee, Murillo Campello (the editor), Martijn Cremers, Cyril Demaria, Ulrich Hege, Thomas Hellmann, Benjamin Hermalin, Victoria Ivashina, Tim Jenkinson, José Liberti, Josh Rauh, David Robinson, Antoinette Schoar, Luke Taylor, Bauke Visser, Annette Vissing-Jorgensen, and seminar participants at the Universities of Nottingham and Tilburg for valuable comments on the paper. Our research assistants provided invaluable help in collecting the data: Jan Peter Gabrielse, Marlon de Haas, Femke Helgers, Joris Hoendervangers, Edvardas Moselka, Robin Rijnders, Jacco Vogels, and especially Yves Kessels. Marco Da Rin is also associated with the European Corporate Governance Institute. We gratefully acknowledge grants from CAREFIN and EIBURS. 


\title{
The Importance of Size in Private Equity: Evidence from a Survey of Limited Partners
}

\begin{abstract}
Using a comprehensive survey, we show that investors with a larger capital allocation to private equity are more specialized - measured by the degree to which the investor focuses on private equity rather than other classes of investments - and have a wider scope of due diligence and investment activities. Other investor characteristics (experience, type, location, compensation structure, number of funds under management) play no role. In particular, Endowments are not special according to the survey measures. These results are consistent with the changing LP-GP relationship in private equity as capital is increasingly concentrated in the hands of large investors.
\end{abstract}


This paper conducts a worldwide survey of Limited Partners (LPs) - the name given to institutional investors which allocate money to Private Equity funds. The goal is to investigate the dimensions along which LPs differ in (i) their due diligence practices regarding their potential investments in private equity funds, and (ii) the extent to which the investment professionals in charge of the private equity portfolio are specialized to that task.

Previous work has pointed toward endowment investors as especially successful, sophisticated and diligent private equity investors. For example, Lerner, Schoar, and Wongsunwai (2007) argue that certain types of investors are better able to process information about opaque asset classes such as private equity. They find evidence that endowments outperform other type of investors on their private equity investment decisions. They further connect this finding to a broader literature, arguing that differences in performance may be caused by differing levels of sophistication in selecting investments, and by 'cultural' differences such as the use of performance-based compensation or high staff turnover rates. On the other hand, Sensoy, Wang, and Weisbach (2014) find that the outperformance of endowments no longer holds in the most recent decade of data. This raises the question of whether endowments really are different from other types of investors and whether, as Sensoy, Wang, and Weisbach (2014) argue, endowments were just lucky in the early part of the sample period because they had access to top venture capital funds at that time. Our paper is uniquely positioned to answer the question of whether endowments are special amongst LPs, because it has direct evidence on what LPs actually do when it comes to selecting and monitoring GPs.

We contacted the (nearly) 2,000 LPs that are listed in the Limited Partners Directory published by Private Equity International, a consultancy firm. We invited these LPs to answer detailed questions about their due diligence process and offered to give them the aggregate results once our survey was finished. This gave these LPs the opportunity to benchmark their due diligence, free-of-charge and anonymously. We obtained 249 sufficiently complete responses spanning 30 countries. Respondents range from Pension Funds and Endowments, to Family Offices. To our knowledge, this is the largest survey of private equity investors to-date in terms of the number of respondents, geographical coverage, and scope.

The main results are easy to summarize: the only consistently significant dimension along which LPs differ in their practices is the size of the private equity portfolio (in absolute value). The institutions with large allocations to private equity are those spending most time on due diligence for each fund and those undertaking the most initiatives in the due diligence process. There are a number of other LP characteristics that are not related to the intensity of due diligence. Perhaps the most notable of these, given prior literature, is whether the LP is an endowment. More broadly, this paper 
sheds new light on the way in which investors seek to address information asymmetries when they invest in opaque asset classes such as private equity.

Firstly, we measure the specialization of investment teams. We ask whether the professionals in charge of private equity investing are also responsible for investing in real estate (a related asset class) or in hedge funds (an unrelated asset class, but one that often goes under the same umbrella of 'alternative investments'), and the fraction of investments that are made via fund-of-funds. We find that LP size is significantly related to each measure of team specialization. Private equity teams at larger LPs are more likely to supervise only private equity funds and invest less via funds-of-funds. Smaller LPs are less specialized, but they outsource their due diligence to a similar extent as larger LPs. Hence those smaller LPs that manage private equity alongside hedge funds and real estate are not just outsourcing due diligence activities. They undertake less due diligence, whether in-house or outsourced.

We then ask investors about due diligence and monitoring activities. We find that investors' scope of activities, including those outsourced, is strongly related to their size. Larger LPs engage in a wider range of due diligence activities, including legal activities (e.g., benchmark and negotiate contracts), accounting activities (e.g., develop their own models to evaluate funds' reported Net Asset Values), co-investing in deals alongside the private equity funds to which they have committed capital, visiting and interviewing portfolio company executives, and sitting on private equity funds' advisory boards. This result holds when controlling for the fraction invested via fund-of-funds to account for the possibility that smaller LPs may outsource indirectly by investing more in fund-offunds. Consistently, we also find that large LPs spend more than twice as much time evaluating a given investment proposal than small LPs.

Our results are robust to the inclusion of control variables that account for alternative explanations. In particular, we control for the fraction of the LP parent's portfolio allocated to private equity and for the existence of performance-based salary. Hence, our results are not driven by organizations exerting higher effort when private equity is a more important part of their portfolio or when employees are better incentivized. Furthermore, we find that larger LPs have more investment professionals but that their number is not strongly related to the scope of activities.

The conditional correlations we document are interesting per se and show a robust pattern in the data. Interpreting these results as causal, however, is challenging. In particular, reverse causality is plausible: some investors start operating in a more thorough way than others and are therefore more successful. Because they are more successful, they end up with more money to manage. Hence it is the wider scope of activities that implies larger LP size and not vice versa. To assess this perspective, we conduct three tests. First, we show that LP size remains strongly correlated to the scope of investor activities for LPs whose allocation depends less on past performance (which we 
ask directly in our survey). Second, we show that the same holds for LPs who have less than ten years of track record. This is particularly salient, as size depends much less on past performance for these LPs. Third, our results hold when we control for the share allocated to private equity by the LP's parent, which under the reverse causality hypothesis, should be the one driving force behind investors' scope of activity. Although we cannot rule out reverse causality, none of these tests support this view.

The rest of the paper is organized as follows: Section 2 describes the data. Section 3 provides empirical evidence on investors' organizational structure; Section 4 provides evidence on investors' scope of due diligence and monitoring activities. Section 5 focuses on the relation between team size and LP size. Section 6 examines investor investment criteria. Section 7 concludes by discussing the implications of our results.

\section{Data and investor characteristics}

\subsection{Survey design}

The survey was designed with the help of a senior LP executive and was presented to investors as a unique opportunity to (anonymously) benchmark their due diligence practices against those of a large set of other investors for free. Respondents do not therefore have clear incentives to misrepresent any information.

To construct our sample of respondents, we used the 2008 Directory of Limited Partners published by Private Equity International (PEI). During the year 2009, we emailed all of the 1,723 LPs listed in the directory to introduce the survey and to provide the website address for responding. ${ }^{1}$ Respondents to the survey could leave their contact details; two thirds did so. When investors left their contact details but did not answer some of the questions, we followed up by phone.

We have received 249 responses from LPs in 30 countries, giving a response rate of $14.4 \%$. This compares well to other academic large-scale surveys. For example, the CFO survey of Graham and Harvey (2001) had a response rate of $8.9 \%$. We believe that this relatively high response rate reflects a significant interest in the investor community about how others perform due diligence. ${ }^{2}$

\subsection{Main investor characteristics and sample representativeness}

From the survey, we obtain LP characteristics that could explain heterogeneity in due diligence practices. Four of these characteristics are also available in PEI and can help us gauge the representativeness of our sample. In this sub-section, we describe these four investor characteristics.

\footnotetext{
${ }^{1}$ The Directory contains several organizations that are GPs, or that no longer invest in private equity. It also contains fund-of-funds, which we exclude.

${ }^{2}$ Groh and Liechtenstein (2011) conduct a similar survey on how investors select venture capital funds.
} 


\subsubsection{LP Type}

The first characteristic we collect is 'LP type', i.e., the nature of the parent organization. This is motivated by the study of Lerner, Schoar, and Wongsunwai (2007), who point out that an important source of heterogeneity across institutional investors is their organizational type. They find that endowments outperform other types, and infer a number of advantages that endowments have over other investor types when it comes to investing in alternative asset classes in general, and in private equity in particular.

We classify LPs into six organizational types: i) Public pension funds, ii) Corporate pension funds, iii) Endowments (which include foundations), iv) Insurance companies, v) Banks and Finance companies, v) Other (mostly sovereign wealth funds and family desks).

The largest category in the sample is public pension funds, comprising almost one third of the respondents. The sample splits fairly equally across the other five types, as shown in Table $1-$ Panel A. The smallest type, corporate pension funds, represents $8 \%$ of the sample. Compared to the PEI universe we have a similar percentage for endowments, insurance companies and banks, more public pension funds and other types (mostly government-owned LPs), and fewer corporate pension funds. Overall, all categories are well represented.

\subsubsection{LP Location}

The second LP characteristic we look at is the country of location of the private equity investment committee (or the person taking the private equity investment decisions). Location may matter in several ways. Investors in North America (USA and Canada) may be seen as more prestigious, and are likely to have access to a better labor market for asset managers; they are also geographically closer to the majority of private equity funds. Second, the rules that investors and private equity funds need to follow vary across countries. Location is therefore a potential source of heterogeneity across investors.

We pool countries to form regions. As shown in Table 1 - Panel B, North American investors are the largest group with $33 \%$ of the respondents. Yet, we have relatively fewer North American investors and more European investors than the PEI Directory population. Our high response rate in Scandinavia is mainly due to the higher willingness of investors in those countries to answer the survey. In North America we had difficulties reaching out to investors; yet, those investors represent the main group in our sample.

\subsubsection{LP Size}


In complex and illiquid asset classes such as private equity, there are substantial fixed costs that may affect the way investments are made. We therefore ask LPs the amount they invest in buyout and the amount they invest in venture capital. The sum of the two is the amount the LP invests in private equity (LP size). We split the sample into five almost equal groups. Table $1-$ Panel C shows the wide dispersion in capital allocated to private equity across investors. Almost one investor in three has less than $\$ 100$ million invested in private equity, while another one in six investors has more than $\$ 2$ billion invested in the same.

We have relatively few very small investors (those with less than $\$ 100$ million in private equity). This group is less well staffed and spends a lot less of their resources in the investment process. Hence filing our survey is more costly for them, and they may see little benefit in participating. In the other size categories, we closely match the proportions of the PEI directory.

\subsubsection{LP Experience}

In asset classes characterized by a large asymmetry of information, such as private equity, investor's experience may be a distinctive factor. It is often argued that early movers in the private equity industry are at an advantage, with the endowments of Yale University and Harvard University often cited as examples (see Fang, Ivashina, and Lerner (2015), Sensoy, Wang, and Weisbach (2014), and Swensen (2000)). In addition, more experienced investors may behave differently as they may have learnt over time how to perform more effective due diligence. They may also expend less effort because they are more productive. Our sample and the PEI universe are fairly close on that dimension (Table 1 - Panel D), with an over-representation of younger investors and underrepresentation of very long-established investors (over 15 years of experience).

$<$ Table $1>$

\section{Organizational Structure and Human Resources}

\subsection{Descriptive statistics}

Table 2 shows descriptive statistics for investor characteristics related to organizational structure and human resources. Panel A shows statistics for continuous variables, and panel B shows statistics for binary variables.

The mean LP size is $\$ 1.3$ billion, with wide variation across LPs. The LP's parent organization, say the insurance company or pension fund that owns it, may play a role in due diligence activities. More experienced parents may have accumulated substantial due diligence experience; may be perceived as a prestigious employer or client; and may have established a strong network of connections that facilitate information gathering. We construct parent experience as the number of years it has been in operation in 2008. On average, the parent organization is 44 years old 
(Table 2 - Panel A). A parent with a large amount of assets under management may give the LP stronger bargaining power. We observe wide variation in this variable, with the $25^{\text {th }}$ percentile at $\$ 0.7$ billion and the $75^{\text {th }}$ percentile at $\$ 15$ billion.

In terms of staffing, we find that the average private equity investment team is composed of 6.4 (full time equivalent) investment professionals, with a skewed distribution. The $25^{\text {th }}$ percentile investor has only one investment professional, and even the $75^{\text {th }}$ percentile investor has five. The number of investment committee members is more narrowly and evenly distributed, with an average of 7.1 members. Interestingly, the inter-quartile range for the investment committee members (four to eight members) is similar to what has been identified in the literature as the optimal size for corporate boards (see Adams, Hermalin, and Weisbach (2010)).

\section{$<$ Table $2>$}

Next, we turn to some variables that measure how money is deployed into private equity. We first compute the allocation to private equity as the ratio of LP size to parent-size (amount under management). This variable provides a clear measure of how important private equity is for the parent's investments. A quarter of the investors have less than $3 \%$ of their funds allocated to private equity while another quarter of the investors have more than $26 \%$.

The number of funds an LP invests into reveals how organizations allocate money. The interquartile range is 9 to 56, which seems quite large given the small number of investment professionals. Taking the ratio, we find that on average one professional is responsible for 17.8 funds, with substantial variation across LPs. The workload is high also in terms of funds per professional, with an average just over $\$ 200$ million per professional and an inter-quartile range of $\$ 40$ million to $\$ 288$ million per professional.

We then consider the characteristics of the individuals who manage the LP, as industry experience or personal networks may have a first-order effect on how investments are made (Kaplan, Sensoy, and Strömberg (2009)). The industry experience of the members of the private equity investment committee averages ten years, and the dispersion across LPs is moderate.

Lerner, Schoar, and Wongsunwai (2007) conjecture that LPs like pension funds may be more prone to staff turnover, with a negative effect on due diligence. We therefore ask LPs how many people have left the investment committee over the previous five years, and define this turnover as the ratio of this number to the number of investment committee members. The average turnover rate is one fourth, and variation is substantial: more than a quarter of the LPs had no turnover at all, while 
a quarter experienced a turnover above $40 \%{ }^{3}$ The last variable in Panel A is the percentage of fundof-funds in the private equity portfolio. This is a measure of the extent to which LPs delegate the investment decision to specialized intermediaries. Many investors have none but the average investor has $18 \%$ of its money in fund-of-funds.

Table 2 - Panel B reports the frequency of several binary variables. We first measure whether the private equity team is also responsible for hedge funds or real estate funds. Hedge funds, real estate and private equity are often all classified as 'alternative investments'. Although there can be some overlap between real estate and private equity in terms of investment skills, because the investment structure is similar (private partnerships), there is hardly any investment skills overlap between hedge funds and private equity. Perhaps surprisingly, then, a striking $31 \%$ of investing teams are also responsible for hedge fund investments. An even higher fraction of the teams (44\%) are responsible for both real estate investments and private equity investments.

The next variable measures the proportion of LPs that choose to delegate due diligence to specialized intermediaries. Half of the LPs say that they outsource part of their due diligence. Therefore, in all questions about due diligence we specify that we are asking for tasks that are carried over either in-house or outsourced.

The large majority of organizations have an investment committee (78\%). Few committees vote with majority rule (24\%); most require a consensus decision. Most committees are autonomous (75\%), meaning that their decisions cannot be modified or vetoed by anyone external.

Our last set of survey questions looks at compensation policy. Well over one third of the organizations (38\%) offer compensation pegged to financial performance; interestingly, this holds for both investment committee members and non-members. The variable part of the salary can be larger than the fixed part in $34 \%$ of the cases for investment committee members, and in $23 \%$ of the cases for other professionals. The use of performance-based compensation is often recent, as $29 \%$ of the respondents say that the compensation policy has changed over the past ten years and that bonuses were introduced.

Such reliance on performance-based compensation may be surprising because returns of private equity funds are notoriously difficult to measure, and they take a very long time to materialize. Interim Net Asset Values (NAV) reported by fund managers are likely to play a role in the bonus of the investing team. Given that the calculation of the NAV contains elements of subjectivity, this can lead to conflicting interests in that both the private equity investing team and the fund manager may accept inflated NAVs in some circumstances.

\footnotetext{
${ }^{3}$ Since almost one fifth of the LPs do not have an investment committee, the number of observations is lower for the investment committee variable.
} 
Overall, Table 2 provides for the first time large-scale evidence on the internal organization and human resources of LPs, contributing to shed light on the 'black box' of LPs. Notably, it documents that internal organization significantly differs across LPs.

\subsection{LP size, team specialization and outsourcing}

We now study how LP characteristics are related to the specialization of the investment team. As in subsequent regressions, we employ a standard set of explanatory variables that include the four LP characteristics described in section 2.2: LP type, location, size, and experience, to which we add the experience of the LP's parent. Following Fang, Ivashina, and Lerner (2015) and Sensoy, Wang, and Weisbach (2014), we choose public pension funds as the omitted type category.

The first two specifications in Table 3 present results from Probit regressions that look at whether private equity teams also manage other investments. In the first specification, the dependent variable is a dummy variable that takes the value of one if the team in charge of private equity investing is also in charge of hedge fund investing, and zero otherwise. In the second specification, the dependent variable is a dummy that identifies teams in charge of both private equity and real estate investments. In the third specification, which is estimated by Tobit, the dependent variable is the fraction of the private equity portfolio that is invested in fund-of-funds; this variable takes a value between $0 \%$ and $100 \%$. In the last specification, which is estimated by Probit, the dependent variable is a dummy variable that takes the value of one if the team declares that part of their due diligence activities are outsourced, and zero otherwise.

\section{$<$ Table $3>$}

We find that larger LPs are more likely to have specialized investment teams. The last two rows of Table 3 report the mean values of the fraction of teams that also manage hedge funds or real estate funds for large and small LPs, defined as LPs in the top and bottom tercile of the size distribution, respectively. This effect is substantive: small LPs are more than twice as likely to manage also real estate assets, and more than three times as likely to manage also hedge funds. The other explanatory variables have little power; except for being an endowment, which decreases team specialization. In column (iii) we also find that larger LPs are less likely to invest in fund-of-funds. This effect is also sizeable. Small LPs invest in fund-of-funds three times as much as large LPs.

Although they are less specialized, small LPs might outsource more due diligence activities. We look at this in column (iv). Type, location and experience affect the decision to outsource some due diligence activities, but investor size does not. Hence, those small LPs that manage private equity alongside hedge funds and real estate are not just outsourcing each type of due diligence more. This is a clear indication that smaller LPs do less due diligence when investing in private equity, even when we take outsourcing into account. 


\section{Investors' Scope of Activities}

Our survey allows us to measure a variety of activities that span different dimensions of investing, which we aggregate into a summary measure of investor activity scope. We first look at descriptive statistics to open up the 'black-box' of private equity investing, and then study cross-sectional differences.

\subsection{Track record evaluation: Accounting and actuarial activities}

A key element that LPs consider when deciding to invest in a GP is past performance. An important challenge in the evaluation of GPs' track record is the valuation of unrealized investments in portfolio companies, i.e. of Net Asset Values (NAVs). This means that past returns reported to LPs largely rely on subjective valuations of unrealized investments. Prospective investors may therefore want to re-evaluate NAVs using their own criteria. Item 1 in Table 4 shows that $24 \%$ of investors do so.

In addition, performance figures provided by GPs are often aggregated. For example, a GP that raises a buyout fund may report performance measures that pool together previous investments in venture capital and buyouts. Likewise, a GP with high returns in its early funds, but not in its later funds, would pool all previous funds together and report only one aggregate performance number. For these reasons, an LP may want to compute its own measure of a GP's past performance. Item 2 in Table 4 shows that $52 \%$ of the LPs always do so (only $12 \%$ of the investors never do so; nontabulated). Finally, Item 3 shows that $77 \%$ of the investors always benchmark a GP's track record.

\subsection{Contract evaluation: Legal activities}

The contractual rights of an investor in a private equity fund are governed by the Limited Partnership Agreement (LPA). ${ }^{4}$ The LPA details the fees to be paid by the LP to the GP and all legal covenants covering their relationship. Because the fees can have a large impact on performance and because the inclusion or exclusion of certain covenants can significantly affect potential conflicts of interest, comparing the LPAs of different funds is an important exercise. It is also a costly one, given that LPAs are technical and lengthy documents, typically over 100 pages. Item 4 of Table 4 shows that $64 \%$ of investors benchmark the LPAs (sometimes or always; only a minority of LPs always do it).

Since the late 1990s, some LPs have started obtaining special rights that are granted via separate 'side letters'. Common reasons given for these are that an investor is considered a strategic or large client, or that the investor is subject to government regulation (e.g., ERISA, the Bank Holding Company Act, or public records laws). In addition, LPs may negotiate a 'Most Favored Nation' (MFN) provision that permits the election of certain benefits granted to other LPs via side

\footnotetext{
${ }^{4}$ Gompers and Lerner (1996), Metrick and Yasuda (2010), and Litvak (2009) study contracts between GPs and LPs.
} 
letters. In general, the MFN provision guarantees that the investor has the best terms granted to any other investor. It is unclear whether any of these side letters are favours granted to investors or whether certain investors need these to clear internal regulations (e.g. in terms of Corporate Social Responsibility). Either way, an investor asking for side letters engages in legal activities.

Items 5 and 6 in Table 4 show that $41 \%$ of the investors always obtain side letters and $36 \%$ of the investors always obtain the MFN clause. As these two proportions are quite similar, it is likely that there are only two LPAs: the default one and a special one, both of which are granted to a large group of investors.

We also ask investors, more broadly, whether they negotiate contract terms (item 7 in Table 4) and 59\% report that they always do (only 15\% report never doing so). This shows that LPAs are not a take-it-or leave-it proposition by the GP, but a document that investors tend to negotiate on in contrast to common beliefs (Litvak (2009)).

\subsection{Direct investment activities: Co-investments and executive interviews}

Co-investing is a growing phenomenon in private equity (Phalippou (2009)): GPs invite LPs to coinvest in a specific company, without charging additional fees. Engaging in co-investments is de facto a reduction in the overall fee bill for the investor that may improve net-of-fees returns. In addition, GPs may overweigh selected LPs in the best investments. At the same time, it is possible that LPs are invited to join less promising investments, larger investments, or have poor market timing abilities.

LPs participating in co-investments engage in extra and costly due diligence to screen this type of opportunity. This is surprising at first sight because a co-investment is just an increase in an existing investment in a given company at no extra cost. However, co-investments increase career concerns. No investment manager would get fired from investing in funds managed by Blackstone or Bain Capital, but one could get fired for undertaking two co-investments offered by those GPs that performed poorly; hence the extra due diligence.

We find that $75 \%$ of the investors in our sample have been invited at least once to co-invest. This is a remarkably high number given the diversity of our participants. However, we also find that the average invitee rejects on average a staggering $74 \%$ of the invitations. Overall, $52 \%$ of the respondents have made at least one co-investment (item 8 in Table 4).

A related activity for investors is interviewing executives of portfolio companies in order to learn whether the GP adds value to the portfolio companies. As in co-investments, this requires LPs to know about company investment processes. In these interviews, LPs also assess whether the GP has a good reputation with entrepreneurs and executives, which is an important factor for assessing the quality of future deal flows. Item 9 in Table 4 shows that $37 \%$ of the investors 'always' interview portfolio company executives (50\% do it sometimes, $13 \%$ never do it; non-tabulated). 


\subsection{Monitoring activities}

Unlike the monitoring of portfolio companies by the GP, the monitoring of the GP by the LP has not been covered in the literature. Because LPs cannot intervene in fund decisions, monitoring does not appear necessary at first sight. In fact, monitoring is useful in case the investor is considering selling its stake in a fund, or purchasing more, in the secondary market. But the most important reason to monitor is preparing due diligence for the reinvestment decision at a fund's next fund-raising. LPs can monitor through a wide range of different actions, most of which are difficult to quantify. We ask three questions to assess monitoring activities.

First, investors may monitor fund managers by sitting on fund advisory boards, provided they are invited to do so by the fund managers. Advisory boards are often designed to provide access to deals or technical expertise. Further, advisory boards have no legal obligations and are less formal than corporate boards of directors, while providing guidance and oversight for the operation of the fund, including portfolio company valuations. Half of the respondents have at least one board seat (item 10 in Table 4).

Second, investors may monitor by keeping track of the composition of the fund's underlying investments in terms of industry, deal size and country. This facilitates the next round of due diligence, and might trigger some intervention on the secondary market. Almost all the investors $(82 \%)$ track the composition of their private equity portfolio (item 11 in Table 4).

Third, we use visits to portfolio companies held by the funds in which the LP is invested as another proxy for monitoring activities. Given that it is a time-consuming action that may require travelling and knowledge about which questions to ask, it is not a systematic practice. Relatively few LPs say they always do it (6\%). A much larger share sometimes visits portfolio companies, but one third of the respondents (35\%) never do so.

$<$ Table $4>$

\subsection{Determinants of investors' scope of activities}

In column (i) of Table 4 we show the frequency of each of the twelve activities described in subsections 4.1 to 4.4. We split this frequency by LP size: column (ii) for large investors (those in the top tercile of LP size), and column (iii) for small investors (those in the bottom tercile of LP size). Small investors are less likely than large investors to undertake ten out of twelve of the activities. Some particularly significant differences are found for legal activities (e.g. 17\% of small investors always obtain side letters versus $63 \%$ of large investors) and for advisory board seats (26\% of small investors have at least one board seat versus $67 \%$ of large investors). 
To capture investors' scope of activities in a single variable, we take the fraction of activities pursued by each investor. ${ }^{5}$ Some pursue very few of the twelve activities and get a score of 0.1 ; some pursue them all and get a score of 100\%. Figure 1 shows the histogram of investors' scope of activities. There is a wide dispersion in scores across our respondents.

Table 5 shows results from Tobit regression analysis in which investors' activity scope measure is the dependent variable. Explanatory variables include the same set of variables as in Table 3: LP size, experience, type, location, and parent experience. We then add each of the investor characteristics listed in Table 2, one at a time. In the interest of space we show only those that are either statistically significant or of particular interest. Across all specifications, our results show LP size to be a highly significant determinant of LP activity scope. In column (i) we omit LP size to explore whether any LP types are strongly correlated with the scope of activities. We find that they are not.

\section{$<$ Figure $1><$ Table $5>$}

Some of the additional explanatory variables from Table 2 also have a significant effect on the scope of due diligence. Organizations with larger amounts of capital under management (parentsize) may have internal legal and accounting departments which could facilitate a broader scope of activities. Results in Table 5 - column (ii) show that this is not the case and that LP size is still the dominating explanatory variable for investors' scope of activities.

The next three specifications use different proxies for staffing as additional control variables (columns (iii), (iv), and (v)). We find that LPs with more private equity professionals have a wider scope of activities. In terms of workload, both the number of funds per investment professional and the amount of assets under management per investment professional are strongly, negatively related to the scope of activities. Accounting for staffing does not affect the statistical significance of LP size.

In addition to these organizational characteristics, the allocation to private equity may also matter. Organizations with relatively little money in private equity may not find it worthwhile to undertake many different due diligence activities. Column (vi) of Table 5 shows that this is not the case, so that the relation to LP size is not driven by organizations exerting higher effort on a more important part of their portfolio. Finally, we look at the three variables that Lerner, Schoar, and Wongsunwai (2007) conjecture may lead to more sophisticated investment practices: performancebased compensation, staff turnover, and the presence of conflicting objectives. Column (vii) of Table

\footnotetext{
${ }^{5}$ We follow the spirit of the corporate governance index of Gompers, Ishii, and Metrick (2003). For investors who do not respond to all questions, we compute the fraction among the questions they answer.
} 
5 shows that performance-based compensation is indeed correlated with the scope of investor activities, but it does not detract from the significance of LP size. Staff turnover is not significantly related to investor activities, and it does not affect the significance of LP size (unreported). We measure the presence of conflicting objectives for the LP by asking for the importance of creating business for the other divisions of the mother organization. This variable also turns out not to be significant and not to affect the significance of LP size (unreported).

While smaller LPs do not outsource due diligence more than larger LPs, they may effectively do so by investing in fund-of-funds. Funds-of-funds are likely to engage in extensive due diligence because this may be beneficial to returns and/or help market the quality of their services as intermediaries, therefore increasing the size of the funds they can raise and thus the fees they earn. To address this concern, we include in all regressions of Table 5 the percentage of fund-of-funds in the portfolio of an LP. Even so, LP size remains the main determinant of the scope of activities.

In unreported results we verify that LP size is a significant determinant of each single component of the investors' activity scope measure; in other words, the significance of LP size does not rely on aggregation.

Table 6 reports results from some robustness tests. First, we exclude LPs that invest more in venture capital than in buyouts (column (i)), since the size of buyout funds is much larger, and the relationship between return and size is different from venture capital. We do not find any difference in results. Second, we address the concern that delegation of activities to fund-of-funds may drive our results by excluding all LPs who invest more than $10 \%$ in these (column (ii)). We find that the relation to LP size is unaffected. The two remaining specifications deal with endogeneity and are covered in the next section.

\subsection{Endogeneity}

LP size is to a certain extent endogenous and this affects the interpretation of our results. The most likely story is one of reverse causality: some investors start operating in a more thorough way than others, and are therefore more successful. Because they are more successful, they end up with more money to manage. Hence, it is wider scope of activities that implies larger-LP size and not vice versa.

We offer three tests of this reverse causality hypothesis. First, we ask investors how much their allocation depends on their own past performance versus the overall industry performance, which is obviously exogenous to LP size. Investors, on average, indicate that industry performance accounts for about $50 \%$ in the determination of their private equity allocation decision, but this percentage varies widely. In column (iii) of Table 6 we report results from the baseline model of Table 5 where we exclude LPs replying that more than half of their allocation decision is due to their own past performance. LP size remains statistically significant, contradicting the reverse causality hypothesis. 
Second, we exclude LPs that have more than ten years of track record. Ten years being the usual duration of a private equity fund, these LPs are expected not to have any fully liquidated funds in their portfolio from which they can learn about their investing abilities. That is, they have little, if any, performance-related information upon which their size could depend. Results are shown in column (iv) of Table 6. Once again, LP size remains statistically significant.

Third, in column (vi) of Table 5 we control for the parent organization's allocation to private equity, which under the reverse causality hypothesis, should be the driving force; we still find that we do not observe any changes in the coefficient on LP size.

Overall, these tests do not support a reverse causality story. However, we cannot rule out this hypothesis.

$$
<\text { Table } 6>
$$

\subsection{Time spent on due diligence}

We now consider investor activity from a different angle. Instead of looking at how many activities LPs carry out, we look at how much time LPs spend on due diligence activities. In the survey, we ask investors how many (full-time equivalent) days of work they typically put in to doing due diligence work for each of three types of funds: first-time funds, seasoned funds of GPs in which the investor has not already invested, and reinvestment decisions ('re-ups'). The respective results from a regression analysis are shown in columns (i) to (iii) of Table 7. We find that LP size has a positive and significant relation with the dependent variables throughout all specifications. The last two rows of Table 7 show that the amount of time spent on due diligence is more than twice as large for large LPs than for small LPs: a very large effect indeed. Interestingly, the effect is largest in the case of first-time funds, where uncertainty is highest. Other LP characteristics play a role only in the case of first time funds: North American LPs spend more time on them, while more experienced LPs spend less time - possibly a sign that they are more productive.

$$
<\text { Table } 7><\text { Table } 8><\text { Table } 9>
$$

\section{Team size}

We now move to analyse the relation between LP size and the size of the private equity team. Our goal is to understand how LPs of different size distribute workloads across their employees, given the large variation in staffing reported in Table 2 . We first run regressions with the number of private equity professionals (team size) as the dependent variable. Results in columns (i) and (ii) in Table 8 show that the relationship between team size and LP size is statistically significant, positive, and linear. Team size, however, is not related to the number of funds in the portfolio, as shown in 
columns (iii) and (iv) of Table 8. This is surprising, because the workload is more likely to be proportional to the number of funds rather than to the amount under management. Investing $\$ 100$ million in one fund should require fewer professionals than investing $\$ 5$ million in twenty funds. Our results in Table 8 show instead that as LP size increases, the workload does not increase as fast, all else equal, and the slack is probably absorbed by the LP taking on more activities. This is consistent with our previous results and corroborates the evidence that larger LPs spend more resources on due diligence activities.

Table 9 further documents these relationships using descriptive statistics broken down by LP size quintiles. The smallest LP quintile contains LPs with less than $\$ 75$ million under management in private equity. The largest LP quintile contains LPs with over \$1 billion under management in private equity. Consistent with our previous findings, we note that the scope of activities increases monotonically across LP size quintiles. The number of private equity funds also goes up with LP size in a linear fashion, but when we look at the number of private equity professionals per fund, it tends to remain constant.

This last result provides an interesting comparison with the predictions of Stein (2002), who argues that larger organizations are more hierarchical and therefore tend to rely more on hard information than smaller ones, because of incentives and communication problems. Berger et al. (2005) confirm these predictions for banks. We show that this may not hold for other financial intermediaries. Larger LPs do not become more hierarchical organizations. Their flat structure and small number of professionals allow the collection, processing, and communication of soft information through due diligence.

\section{Fund selection criteria}

Finally, we ask investors to rank a large set of investing criteria that they use to select funds in order to analyse the relationship between LP size and the criteria LP use to select GPs. This question is asked separately for three types of funds: first-time funds, seasoned funds of firms in which the investor is not already invested, and reinvestment decisions ('re-ups'). We consolidate their answers across all three sets of questions and standardize them so they are comparable across investors. ${ }^{6}$

Table 10 shows the results from regression analyses. The five retained specifications correspond to the questions whose score was most significantly related to LP size. First, smaller LPs give a significantly higher score to the importance of 'commitments by other LPs' as an investment criterion (Table 10, column (i)).

\footnotetext{
${ }^{6} \mathrm{We}$ subtract from each score the average investor score to that question and divide by its standard deviation.
} 
Second, smaller LPs also give more importance to 'advisor and gatekeeper opinion' (Table 10, column (ii)). This is consistent with smaller LPs believing that their due diligence is limited. These two results are in line with our findings above that larger LPs conduct more thorough due diligence, and therefore pay little attention to both external advice and what others do.

Third, the fund selection criterion receiving the largest score is past performance, measured as either IRR or Multiple (i.e. total amount distributed divided by total amount invested). This result is consistent with empirical studies showing that fundraising in private equity is related to past returns in the asset class (Kaplan and Strömberg (2009), Gompers and Lerner (1998)). However, the importance of past performance is unclear. Phalippou (2010) and more recently, Brown, Gredil, and Kaplan (2015) show that past performance, if computed at the time of fund-raising, does not predict future performance. The literature has also pointed out that performance measures such as the IRR are often misleading in a private equity context, while Multiple is a more robust measure of performance (Harris, Jenkinson, and Kaplan (2014), Phalippou (2008)). We find that $18 \%$ of the respondents select past IRR as the most important criteria, while only $13 \%$ of the respondents select Multiple as the most important. Moreover, Table 10 column (iii) shows that larger LPs give a significantly higher score to past Multiple than do smaller LPs. For IRR, smaller LPs tend to give a higher score, but this effect is not statistically significant.

Fourth, larger LPs give a significantly higher score to the importance of both 'fund-size' and 'valuation of unrealized investments' To assess whether either the fund-size or the valuation of unrealized investments is appropriate, it is necessary to have conducted thorough due diligence. One interpretation is that smaller LPs are not in a position to judge the appropriateness of these two important investment criteria, consistent with our findings on investors' scope.

As the last two rows of Table 10 show, the difference between large and small LPs is consistent across investment criteria. These results are also consistent with investors believing that there are increasing returns to scale for due diligence in an asset such as private equity funds.

$<$ Table $10>$

\section{Conclusion}

Industry observers (e.g., Swensen (2000)) have argued that endowments are better equipped to assess and evaluate emerging alternative investments, such as private equity, in which asymmetric information problems are especially severe. Lerner, Schoar, and Wongsunwai (2007) document that improved access, as well as experience of investing in the private equity sector, led endowments to outperform other institutional investors substantially during the 1990s.

Private equity, however, is no longer an emerging and unfamiliar asset class. Investors such as the Canadian CPPIB and the Dutch AlpInvest have built private equity portfolios worth over $\$ 50$ 
billion each in just over a decade. In contrast, both the Yale and Harvard endowments, pioneer investors in that asset class, have private equity portfolios worth around $\$ 5$ billion. The emergence of very large investors goes hand in hand with the disintermediation of private equity. Large investors either co-invest alongside funds or even bypass funds altogether (Fang, Ivashina, and Lerner (2015)). Sensoy, Wang, and Weisbach (2014) have documented that the outperformance of endowments no longer holds in more recent years.

Using a large-scale survey, we document for the first time how private equity investors approach their investment decisions. We show that institutional investors exhibit considerable heterogeneity in their structure, behaviour, and investment criteria. LP size is the only variable that consistently captures this variation. The rapid concentration in the asset management industry should therefore significantly change the characteristics and behaviour of the average investor.

We lack a truly exogenous source of LP size variation that would allow us to make a clear causal interpretation of our results. As we discuss in section 4.6, a reverse causality interpretation is equally likely, though we provide tests that are at odds with this view. In either case, there is no implication that larger LP size should bring higher returns, given decreasing returns to scale in deploying capital.

An interpretation in which the rise of larger asset managers leads to an increase in screening and monitoring activities is also consistent with the balance of power tilting towards investors and away from fund managers, as documented by recent studies for several dimensions. First: decreased accounting manipulation by private equity partnerships at the time of fund-raising, which is largely limited to small funds backed by small investors (see Brown, Gredil, and Kaplan (2015) and Barber and Yasuda (2013)). Second: increased disintermediation in private equity, especially by the largest investors (see Fang, Ivashina, and Lerner (2015)). Third: increased access to the best-performing private equity funds, except for small and specialized venture capital funds (see Sensoy, Wang, and Weisbach (2014)).

Such interpretation also has implications for the organizational design of institutional investors. For example, consider the decision to invest in private equity for a Norwegian or Chinese Sovereign Wealth fund - among the largest asset owners in the world, yet private equity novices. On the one hand, it might be difficult for these investors to enter private equity because they have little experience and lack relationships with funds. On the other hand, perhaps all you need is cash. Our results suggest that if the Norwegian sovereign wealth fund invested $1 \%$ of its $\$ 7.5$ billion capital in private equity we would expect the same type of due diligence, fund terms and conditions, GP monitoring, and investment criteria as for Yale's endowment, with $30 \%$ of its $\$ 20$ billion fund allocated to private equity. Whether this should lead to higher returns, however, is not clear and is a promising avenue for future research. 
In addition to opening the black box of investors' organizational and decision-making processes in a major asset class, this paper shows that investor size is an important statistic to capture investor heterogeneity. The literature studying issues related to investor size focuses mainly on the returns of financial intermediaries. Our study, in contrast, focuses on the interaction between organizational structure and actions in what is arguably the most complex and specialized type of assets to which investors allocate capital: private equity. We therefore contribute to the literature debating which investor characteristics matter in complex and specialized asset classes. 


\section{References}

Adams, Renée B, Benjamin E Hermalin, and Michael S Weisbach, 2010, The Role of Boards of Directors in Corporate Governance: A Conceptual Framework and Survey, Journal of Economic Literature 48, 58-107.

Barber, Brad M., and Ayako Yasuda, 2013, Interim Fund Performance and Fundraising in Private Equity, SSRN Electronic Journal.

Berger, Allen N, Nathan H Miller, Mitchell A Petersen, Raghuram G Rajan, and Jeremy C Stein, 2005, Does function follow organizational form? Evidence from the lending practices of large and small banks, Journal of Financial Economics 76, 237-269.

Brown, Gregory W, Oleg Gredil, and Steven N Kaplan, 2015, Do Private Equity Funds Game Returns?, Working paper.

Fang, Lily, Victoria Ivashina, and Josh Lerner, 2015, The Disintermediation of Financial Markets: Direct Investing in Private Equity, Journal of Financial Economics 116, 160-178.

Gompers, Paul A, and Josh Lerner, 1998, What Drives Venture Capital Fundraising?, Brookings Papers on Economic Activity, 149.

Gompers, Paul, Joy Ishii, and Andrew Metrick, 2003, Corporate Governance And Equity Prices, Quarterly Journal of Economics 118, 107.

Gompers, Paul, and Josh Lerner, 1996, The Use of Covenants: an Empirical Analysis of Venture Partnership Agreements, Journal of Law \& Economics 39, 463-498.

Graham, John R, and Campbell R Harvey, 2001, The theory and practice of corporate finance : evidence from the field, Journal of Financial Economics 60, 187-243.

Groh, Alexander Peter, and Heinrich Liechtenstein, 2011, International Allocation Determinants of Institutional Investments in Venture Capital and Private Equity Limited Partnerships, International Journal of Banking, Accounting and Finance 3, 176-206.

Harris, Robert S, Tim Jenkinson, and Steven N Kaplan, 2014, Private Equity Performance: What Do We Know?, Journal of Finance, 1857-1882.

Kaplan, Steven N, Berk A Sensoy, and Per Johan Strömberg, 2009, Should Investors Bet on the Jockey or the Horse? Evidence from the Evolution of Firms from Early Business Plans to Public Companies, Journal of Finance 64, 75-115.

Kaplan, Steven N, and Per Johan Strömberg, 2009, Leveraged Buyouts and Private Equity, Journal of Economic Perspectives 23, 121-146.

Lerner, Josh, Antoinette Schoar, and Wang Wongsunwai, 2007, Smart Institutions, Foolish Choices: The Limited Partner Performance Puzzle, Journal of Finance 62, 731-764.

Litvak, Kate, 2009, Venture Capital Partnership Agreements: Understanding Compensation Arrangements, University of Chicago Law Review 76, 161-218.

Metrick, Andrew, and Ayako Yasuda, 2010, The Economics of Private Equity Funds, Review of Financial Studies 23, 2303-2341. 
Phalippou, Ludovic, 2008, The hazards of using IRR to measure performance: The case of private equity, Journal of Performance Measurement, 1-23.

Phalippou, Ludovic, 2009, Beware of Venturing into Private Equity, Journal of Economic Perspectives 23, 147-166.

Phalippou, Ludovic, 2010, Venture capital funds: Flow-performance relationship and performance persistence, Journal of Banking \& Finance 34, 568-577.

Sensoy, Berk A, Yingdi Wang, and Michael S Weisbach, 2014, Limited Partner Performance and the Maturing of the Private Equity Industry, Journal of Financial Economics 112, 320-343.

Stein, Jeremy C, 2002, Information Production and Capital Allocation: Decentralized versus Hierarchical Firms., Journal of Finance 57, 1891-1921.

Swensen, D F, 2000, Pioneering Portfolio Management: An Unconventional Approach to Institutional Investment (Simon \& Schuster). 


\section{Table 1 - Main investor characteristics and sample representativeness}

This table shows descriptive statistics for the variables defined in section 2.2. PEI Universe is the list of investors contained in the 2008 Private Equity International (PEI) Directory. Our sample includes only respondents providing their type (Panel A), location (Panel B), amount of private equity capital under management (Panel C) and year of first investment in private equity (Panel D).

Panel A: LP type (investor category)

\begin{tabular}{lccc}
\hline LP type & Obs. & $\begin{array}{c}\text { Fraction in } \\
\text { our sample }\end{array}$ & $\begin{array}{c}\text { Fraction in } \\
\text { PEI Universe }\end{array}$ \\
\cline { 2 - 4 } Public pension funds & 76 & $31 \%$ & $21 \%$ \\
Corporate pension funds & 20 & $8 \%$ & $21 \%$ \\
Endowments & 43 & $17 \%$ & $21 \%$ \\
Insurance companies & 24 & $10 \%$ & $8 \%$ \\
Banks/Finance companies & 46 & $18 \%$ & $23 \%$ \\
Others & 40 & $16 \%$ & $6 \%$ \\
\hline
\end{tabular}

Panel B: Region of LP location

\begin{tabular}{lccc}
\hline LP Region & Obs. & $\begin{array}{c}\text { Fraction in } \\
\text { our sample }\end{array}$ & $\begin{array}{c}\text { Fraction in } \\
\text { PEI Universe }\end{array}$ \\
\cline { 2 - 4 } North America & 81 & $33 \%$ & $56 \%$ \\
Continental Europe & 56 & $22 \%$ & $16 \%$ \\
Scandinavia & 35 & $14 \%$ & $5 \%$ \\
United Kingdom & 30 & $12 \%$ & $8 \%$ \\
Australia & 15 & $6 \%$ & $4 \%$ \\
Japan & 12 & $5 \%$ & $5 \%$ \\
Rest of the World & 20 & $8 \%$ & $4 \%$ \\
\hline
\end{tabular}

Panel C: LP size (Amount of private equity capital under management, 2008; \$ million)

\begin{tabular}{lccc}
\hline LP size & Obs. & $\begin{array}{c}\text { Fraction in } \\
\text { our sample }\end{array}$ & $\begin{array}{c}\text { Fraction in } \\
\text { PEI Universe }\end{array}$ \\
\cline { 2 - 4 } $0 \leq .<100$ & 72 & $29 \%$ & $36 \%$ \\
$100 \leq .<250$ & 36 & $14 \%$ & $17 \%$ \\
$250 \leq .<600$ & 55 & $22 \%$ & $17 \%$ \\
$600 \leq .<2000$ & 50 & $20 \%$ & $15 \%$ \\
.$\geq 2000$ & 36 & $14 \%$ & $15 \%$ \\
\hline
\end{tabular}

Panel D: LP experience (2008 minus the year firm started to invest in private equity)

\begin{tabular}{lccc}
\hline LP experience & Obs. & $\begin{array}{c}\text { Fraction in } \\
\text { our sample }\end{array}$ & $\begin{array}{c}\text { Fraction in } \\
\text { PEI Universe }\end{array}$ \\
\cline { 2 - 4 } $0 \leq .<4$ years & 48 & $19 \%$ & $11 \%$ \\
$4 \leq .<7$ years & 34 & $14 \%$ & $12 \%$ \\
$7 \leq .<10$ years & 55 & $22 \%$ & $19 \%$ \\
$10 \leq .<15$ years & 57 & $23 \%$ & $22 \%$ \\
.$\geq 15$ years & 55 & $22 \%$ & $36 \%$ \\
\hline
\end{tabular}




\section{Table 2: Organizational Structure and Human Resources}

This table provides descriptive statistics for the variables measuring LP organizational structure and human resources management. Variables are defined in section 3.1. Panel A reports statistics for continuous variables and Panel B for binary variables.

Panel A: Descriptive statistics: continuous variables

\begin{tabular}{lrrrrc}
\hline & Mean & St. Dev. & \multicolumn{2}{c}{ Percentile } \\
& & & $25^{\text {th }}$ & $75^{\text {th }}$ & Obs. \\
\cline { 2 - 5 } LP size (\$ million) & 1,291 & 3,550 & 75.71 & 943.8 & 242 \\
Parent experience (years) & 43.77 & 51.51 & 10.00 & 57.00 & 242 \\
Parent size (\$ billion) & 32.33 & 108.01 & 0.70 & 14.91 & 219 \\
Number of PE professionals & 6.42 & 12.08 & 1.00 & 5.00 & 172 \\
Number of Investment committee (IC) members & 7.10 & 6.76 & 4.00 & 8.00 & 163 \\
Private equity allocation (\%) & 0.25 & 0.34 & 0.03 & 0.26 & 219 \\
Number of funds held & 37.62 & 43.16 & 9.00 & 56.00 & 167 \\
Funds per PE professional & 17.88 & 21.45 & 4.27 & 23.12 & 144 \\
Dollars per PE professional (\$ million) & 205.91 & 217.64 & 39.50 & 288.90 & 172 \\
Average IC members experience (years) & 10.02 & 5.38 & 6.00 & 13.08 & 129 \\
Investment Committee turnover & 0.27 & 0.37 & 0.00 & 0.40 & 99 \\
Fund-of-funds in portfolio (\%) & 0.18 & 0.22 & 0.00 & 0.33 & 155 \\
\hline
\end{tabular}

Panel B: Descriptive statistics: binary variables

$$
\text { Answers: yes (=1), no }(=0)
$$

PE team also manages hedge funds

PE team also manages real estate

\begin{tabular}{cc} 
Frequency & Obs. \\
\hline 0.31 & 239 \\
0.44 & 239 \\
0.50 & 175 \\
0.78 & 216 \\
0.24 & 207 \\
0.75 & 121 \\
0.38 & 180 \\
0.34 & 64 \\
0.42 & 179 \\
0.23 & 66 \\
0.29 & 179
\end{tabular}

Outsource some due diligence or monitoring activities

Do you have an Investment Committee (IC)?

Are IC decisions taken by majority voting?

Are the IC decisions completely autonomous?

Is part of the IC compensation related to financial performance?

.If yes, Is the bonus larger than the fixed salary?

Do other investment professionals receive a bonus?

. If yes, Is the bonus larger than the fixed salary?

0.23

179

Has the compensation policy changed over the past 10 years? 


\section{Table 3: LP size and team specialization}

This table reports results from Probit and Tobit regressions. The dependent variable differs in each specification. In column (i) the dependent variable is a dummy variable that takes the value one if the team in charge of private equity is also in charge of hedge fund investing, and zero otherwise. In column (ii) the dependent variable is a dummy variable that takes the value one if the team in charge of private equity is also in charge of real estate investing, and is zero otherwise. In column (iii) the dependent variable is the percentage of the PE portfolio that is invested in fund-of-funds. In column (iv) the dependent variable is a dummy variable that takes the value one if part of the due diligence activities are outsourced (and zero otherwise). The explanatory variables are defined in sections 2.2 and 3.1. Specifications (i), (ii), and (iv) are estimated by Probit, and specification (iii) by Tobit. A constant is included but not shown. $t$-statistics are reported in italics between parentheses. Significance levels are indicated by a (1\%), b (5\%), and c $(10 \%)$.

(i)

(ii)

(iii)

(iv)

Team also manages Team also manages \% fund-of-funds Outsource some

LP size $(\log )$ Hedge Funds Real Estate in PE portfolio due diligence

Corporate pension funds

$-0.18^{\mathrm{a}}$

$-0.16^{\mathrm{a}}$

$-0.06^{\mathrm{a}}$

$-0.08$

$(-3.22)$

$(-2.88)$

$(-4.04)$

$(-1.18)$

0.39

$0.68^{\mathrm{c}}$

$-0.02$

0.27

(1.13)

(1.95)

$(-0.18)$

(0.62)

Endowments

$0.78^{\mathrm{a}}$

$0.98^{\mathrm{a}}$

$-0.04$

0.06

(2.63)

(3.17)

$(-0.50)$

(0.17)

Insurance companies

0.06

$-0.07$

0.01

$-0.31$

(0.16)

$(-0.22)$

(0.13)

$(-0.89)$

Banks/Finance companies

0.08

$-0.69^{\mathrm{b}}$

$-0.11$

$-1.28^{\mathrm{a}}$

(0.26)

$(-2.40)$

$(-1.55)$

$(-3.56)$

Other LP types

0.04

$-0.42$

$-0.18^{\mathrm{a}}$

$-0.62^{b}$

North America

(0.14)

$(-1.54)$

$(-2.62)$

$(-2.07)$

\begin{tabular}{lcccc} 
North America & -0.09 & 0.07 & 0.00 & $-0.48^{\mathrm{c}}$ \\
Continental Europe & $(-0.41)$ & $(0.32)$ & $(-0.07)$ & $(-1.89)$ \\
& -0.30 & 0.13 & 0.09 & $-0.61^{\mathrm{b}}$ \\
LP experience $(\log )$ & $(-1.17)$ & $(0.51)$ & $(1.43)$ & $(-2.16)$ \\
& -0.03 & -0.07 & 0.01 & $-0.33^{\mathrm{c}}$ \\
Parent experience $(\log )$ & $(-0.23)$ & $(-0.50)$ & $(0.37)$ & $(-1.91)$ \\
& 0.07 & 0.00 & 0.00 & 0.13 \\
(OLS) R-square & $(0.78)$ & $(0.05)$ & $(0.09)$ & $(1.26)$ \\
Number of observations & 15.0 & 22.5 & 17.4 & 21.1 \\
Mean value of the dependent variable for: & 239 & 155 & 175 \\
Small LPs & 0.52 & & & \\
Large LPs & 0.15 & 0.61 & 0.25 & 0.56 \\
\hline
\end{tabular}




\section{Table 4: Measuring the scope of investor activities}

This table reports the frequency at which investor activities are undertaken. Each investor activity is defined in section 4. Frequency is reported for the whole sample, for the sub-samples of large investors (top LP size tercile), and small investors (bottom LP size tercile). The bottom row reports the scaled investor activity scope measure, defined in section 4.5, averaged across investors. We require a minimum of three entries to compute an LP's scaled investor activity scope measure of scope. In the last column the superscripts $\mathrm{a}, \mathrm{b}$ and $\mathrm{c}$ indicate whether the frequencies for the subsample of large investors are statistically different from these for the sub-sample of small investors at the $1 \%, 5 \%$ and $10 \%$ significance level, respectively.

\section{Accounting activities}

1 Use own fair value of unrealized investments Actuarial activities

2 Always calculate own GP past performance measure

3 Always benchmark GP track record

\section{Legal activities}

4 Benchmark contracts (LPAs)

5 Always obtain side letters

6 Always obtain 'Most Favored Nation' clause

7 Always negotiate contract terms Investment activities

8 Has co-invested alongside a PE fund

9 Always interview portfolio company executives Monitoring activities

10 Has advisory board seats on some PE funds

11 Track PE portfolio mix (industry/size/country)

12 Has visited portfolio companies
Fraction of investors undertaking the activity among:

\begin{tabular}{cccc}
\hline \multirow{3}{*}{ Obs. } & (i) & (ii) & (iii) \\
& All & Large & Small \\
& LPs & LPs & LPs \\
\hline
\end{tabular}

$\begin{array}{llll}143 & 0.24 & 0.37 & 0.21^{\mathrm{b}}\end{array}$

$\begin{array}{llll}184 & 0.52 & 0.60 & 0.47^{\mathrm{c}}\end{array}$

$\begin{array}{llll}179 & 0.77 & 0.84 & 0.65^{\mathrm{a}}\end{array}$

$\begin{array}{llll}185 & 0.64 & 0.66 & 0.56 \\ 174 & 0.41 & 0.63 & 0.17^{\mathrm{a}} \\ 171 & 0.36 & 0.55 & 0.13^{\mathrm{a}} \\ 172 & 0.59 & 0.74 & 0.36^{\mathrm{a}}\end{array}$

$\begin{array}{llll}189 & 0.52 & 0.70 & 0.33^{\mathrm{a}}\end{array}$

$\begin{array}{llll}189 & 0.37 & 0.41 & 0.32\end{array}$
Scaled investor activity scope measure:

\begin{tabular}{llll}
185 & 0.49 & 0.67 & $0.26^{\mathrm{a}}$ \\
177 & 0.82 & 0.88 & $0.72^{\mathrm{a}}$ \\
165 & 0.65 & 0.70 & $0.47^{\mathrm{a}}$ \\
\hline 242 & 0.46 & 0.59 & $0.34^{\mathrm{a}}$
\end{tabular}




\section{Table 5: Determinants of the scope of investor activities}

This table reports results from seven Tobit regression models where the dependent variable is the scaled investor activity scope measure defined in section 4.5; this variable takes values between zero and one. The explanatory variables common to all specifications are defined in section 2.2; the other explanatory variables are defined in section 3.1. A constant is included but not shown. $t$ statistics are reported in italics between parentheses. Significance levels in regressions are indicated by a $(1 \%), \mathrm{b}(5 \%)$, and c $(10 \%)$.

\begin{tabular}{|c|c|c|c|c|c|c|c|}
\hline & (i) & (ii) & (iii) & (iv) & (v) & (vi) & (vii) \\
\hline \multirow[t]{2}{*}{ LP size $(\log )$} & & $0.07^{\mathrm{a}}$ & $0.05^{\mathrm{a}}$ & $0.07^{\mathrm{a}}$ & $0.07^{\mathrm{a}}$ & $0.06^{\mathrm{a}}$ & $0.06^{\mathrm{a}}$ \\
\hline & & $(5.43)$ & $(4.06)$ & (5.83) & (6.63) & $(6.47)$ & (5.68) \\
\hline \multirow[t]{2}{*}{ Corporate pension funds } & -0.06 & -0.04 & -0.05 & -0.04 & -0.01 & -0.04 & -0.05 \\
\hline & $(-1.12)$ & $(-0.62)$ & $(-0.76)$ & $(-0.59)$ & $(-0.21)$ & $(-0.61)$ & $(-0.91)$ \\
\hline \multirow[t]{2}{*}{ Endowments } & -0.08 & -0.07 & -0.02 & -0.02 & -0.02 & -0.07 & -0.07 \\
\hline & $(-1.63)$ & $(-1.49)$ & $(-0.42)$ & $(-0.34)$ & $(-0.46)$ & $(-1.52)$ & $(-1.35)$ \\
\hline \multirow[t]{2}{*}{ Insurance companies } & -0.04 & -0.02 & -0.07 & -0.03 & $-0.09^{c}$ & -0.03 & -0.05 \\
\hline & $(-0.81)$ & $(-0.35)$ & $(-1.36)$ & $(-0.43)$ & $(-1.74)$ & $(-0.50)$ & $(-0.90)$ \\
\hline \multirow[t]{2}{*}{ Banks/Finance companies } & -0.07 & $-0.08^{\mathrm{c}}$ & $-0.13^{\mathrm{a}}$ & $-0.11^{b}$ & $-0.13^{\mathrm{a}}$ & $-0.08^{c}$ & $-0.11^{\mathrm{b}}$ \\
\hline & $(-1.51)$ & $(-1.81)$ & $(-2.87)$ & $(-2.24)$ & $(-2.94)$ & $(-1.80)$ & $(-2.36)$ \\
\hline \multirow[t]{2}{*}{ Other LP types } & -0.07 & $-0.08^{\mathrm{c}}$ & $-0.10^{\mathrm{b}}$ & -0.06 & $-0.10^{\mathrm{b}}$ & $-0.09^{\mathrm{b}}$ & $-0.11^{\mathrm{b}}$ \\
\hline & $(-1.31)$ & $(-1.79)$ & $(-2.32)$ & $(-1.28)$ & $(-2.34)$ & $(-2.00)$ & $(-2.35)$ \\
\hline \multirow[t]{2}{*}{ North America } & & 0.01 & 0.03 & 0.03 & 0.03 & 0.01 & 0.01 \\
\hline & & $(0.18)$ & $(0.85)$ & $(0.81)$ & $(0.96)$ & $(0.20)$ & $(0.33)$ \\
\hline \multirow[t]{2}{*}{ Continental Europe } & & -0.02 & -0.01 & -0.06 & -0.01 & -0.03 & -0.01 \\
\hline & & $(-0.59)$ & $(-0.24)$ & $(-1.52)$ & $(-0.28)$ & $(-0.72)$ & $(-0.26)$ \\
\hline \multirow[t]{2}{*}{ LP experience $(\log )$} & & $-0.04^{\mathrm{c}}$ & $-0.05^{\mathrm{b}}$ & $-0.05^{\mathrm{b}}$ & $-0.06^{\mathrm{b}}$ & -0.04 & $-0.05^{\mathrm{c}}$ \\
\hline & & $(-1.65)$ & $(-2.08)$ & $(-2.02)$ & $(-2.29)$ & $(-1.58)$ & $(-1.88)$ \\
\hline \multirow[t]{2}{*}{ Parent experience $(\log )$} & & -0.02 & -0.01 & 0.00 & -0.01 & -0.02 & -0.01 \\
\hline & & $(-1.31)$ & $(-0.95)$ & $(-0.03)$ & $(-0.39)$ & $(-1.26)$ & $(-0.81)$ \\
\hline \multirow[t]{2}{*}{ Fund-of-funds in portfolio (\%) } & & $-0.12^{\mathrm{c}}$ & -0.06 & -0.01 & -0.02 & $-0.12^{\mathrm{c}}$ & $-0.12^{\mathrm{c}}$ \\
\hline & & $(-1.71)$ & $(-0.76)$ & $(-0.15)$ & $(-0.31)$ & $(-1.73)$ & $(-1.65)$ \\
\hline \multirow[t]{2}{*}{ Parent size (log) } & & 0.00 & & & & & \\
\hline & & $(-0.46)$ & & & & & \\
\hline \multirow[t]{2}{*}{ Number of PE professionals } & & & $0.04^{\mathrm{c}}$ & & & & \\
\hline & & & $(1.88)$ & & & & \\
\hline \multirow[t]{2}{*}{ Funds per PE professional } & & & & $-0.02^{\mathrm{a}}$ & & & \\
\hline & & & & $(-2.58)$ & & & \\
\hline \multirow[t]{2}{*}{ Dollars per PE professional } & & & & & $-0.01^{\mathrm{a}}$ & & \\
\hline & & & & & $(-2.60)$ & & \\
\hline \multirow[t]{2}{*}{ PE allocation $(\%)$} & & & & & & 0.02 & \\
\hline & & & & & & $(0.53)$ & \\
\hline \multirow[t]{2}{*}{ Performance-based compensation } & & & & & & & $0.07^{\mathrm{c}}$ \\
\hline & & & & & & & $(1.95)$ \\
\hline (OLS) R-square & 5.1 & 33.4 & 35.5 & 38.1 & 36.7 & 33.0 & 32.7 \\
\hline Number of observations & 180 & 180 & 155 & 127 & 155 & 181 & 178 \\
\hline
\end{tabular}




\section{Table 6: Robustness tests}

This table reports results from Tobit regression models where the dependent variable is the scaled investor activity scope measure defined in section 4.5; this variable takes values between zero and one. The explanatory variables are defined in sections 2.2 and 3.1. In each column some LPs are excluded from the sample: in column (i) LPs that invest more of their PE portfolio in venture capital than in buyouts, in column (ii) LPs that invest more than $10 \%$ of their PE portfolio in fund-of-funds, in column (iii) LPs that base their allocation to private equity mostly on their own past performance, in column (iv) LPs that have been active in private equity since before 1998. A constant is included but not shown. $t$-statistics are reported in italics between parentheses. Significance levels in regressions are indicated by a (1\%), b (5\%), and c (10\%).

\begin{tabular}{lcccc}
\hline \multirow{2}{*}{$\begin{array}{c}\text { Exclude from the } \\
\text { sample LPs investing: }\end{array}$} & $\begin{array}{c}\text { (i) } \\
\text { more in VC } \\
\text { than in BO }\end{array}$ & $\begin{array}{c}\text { (ii) } \\
\text { more than } 10 \%\end{array}$ & $\begin{array}{c}\text { (iii) } \\
\text { in fund-of-funds a }\end{array}$ & $\begin{array}{c}\text { (iv) } \\
\text { function of their } \\
\text { past performance }\end{array}$ \\
\cline { 2 - 5 } LP size (log) & $0.07^{\mathrm{a}}$ & $0.07^{\mathrm{a}}$ & $0.07^{\mathrm{a}}$ & $0.07^{\mathrm{a}}$ \\
& $(4.54)$ & $(6.94)$ & $(6.85)$ & $(5.53)$ \\
Corporate pension funds & -0.04 & -0.03 & -0.05 & -0.08 \\
& $(-0.37)$ & $(-0.55)$ & $(-0.73)$ & $(-0.82)$ \\
Endowments & 0.04 & -0.08 & -0.04 & -0.03 \\
Insurance companies & $(0.45)$ & $(-1.57)$ & $(-0.71)$ & $(-0.42)$ \\
& 0.05 & -0.07 & -0.04 & -0.02 \\
Banks/Finance companies & $(0.42)$ & $(-1.30)$ & $(-0.67)$ & $(-0.30)$ \\
Other LP types & -0.04 & $-0.09^{\mathrm{b}}$ & $-0.12^{\mathrm{b}}$ & -0.05 \\
& $(-0.51)$ & $(-2.01)$ & $(-2.15)$ & $(-0.88)$ \\
North America & 0.01 & $-0.10^{\mathrm{b}}$ & -0.06 & -0.01 \\
& $(0.18)$ & $(-2.24)$ & $(-1.15)$ & $(-0.19)$ \\
Continental Europe & $0.11^{\mathrm{c}}$ & 0.04 & 0.04 & 0.03 \\
& $(1.81)$ & $(0.98)$ & $(0.91)$ & $(0.60)$ \\
LP experience (log) & -0.10 & -0.01 & -0.02 & -0.07 \\
Parent experience (log) & $(-1.47)$ & $(-0.33)$ & $(-0.37)$ & $(-1.37)$ \\
Number of observations & -0.02 & $-0.04^{\mathrm{c}}$ & 0.01 & -0.03 \\
& $(-0.48)$ & $(-1.75)$ & $(0.32)$ & $(-0.89)$ \\
& $-0.05^{\mathrm{b}}$ & -0.02 & -0.02 & $-0.04^{\mathrm{b}}$ \\
& $(-2.03)$ & $(-1.44)$ & $(-1.08)$ & $(-2.05)$ \\
\hline
\end{tabular}




\section{Table 7: LP size and time spent on due diligence}

This table reports results from OLS regressions. In the first three columns the dependent variable is a the number of (full-time-equivalent) days spent on due diligence (in-house and outsourced) for different types of private equity funds. In column (i) the due diligence is for first time funds, in column (ii) for first investments in a fund operated by an already active ('seasoned') GP, and in column (iii) for re-investments in funds operated by GPs into which the LP has already invested ('re-up'). The explanatory variables are defined in section 2.2. A constant is included but not shown. $t$-statistics are reported in italics between parentheses. Significance levels in regressions are indicated by a (1\%), b (5\%), and c $(10 \%)$.

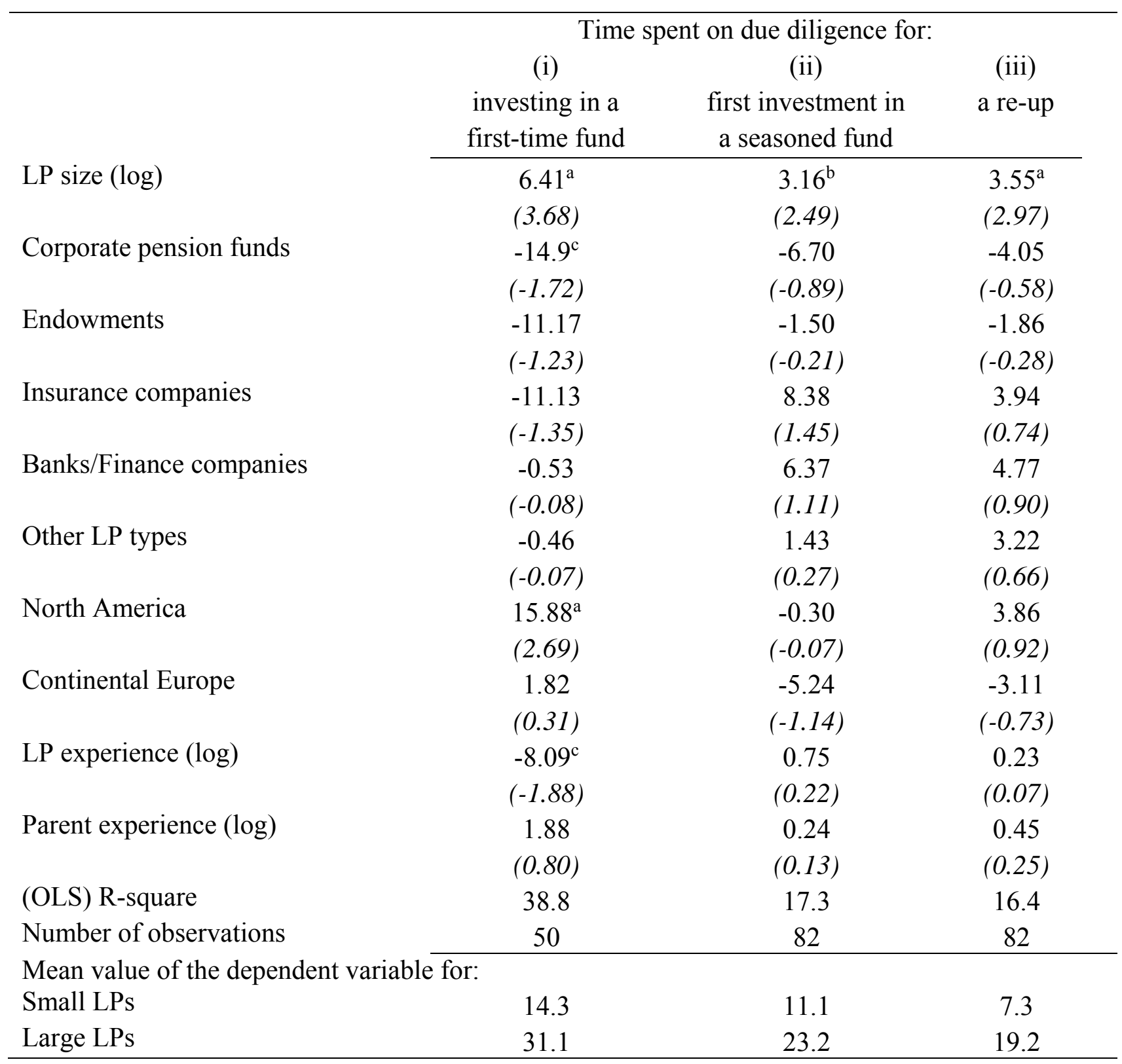




\section{Table 8: Number of employees and LP size - Regression analysis}

This table reports results from OLS regressions whose dependent variable is the number of PE professionals employed by LPs. The explanatory variables are defined in section 2.2; LP size is measured in US dollars billion. t-statistics based on robust standard errors are reported in italics between parentheses. Significance levels in regressions are indicated by a (1\%), b (5\%), and c $(10 \%)$.

\begin{tabular}{lcccc}
\hline \multirow{2}{*}{ Constant } & (i) & (ii) & (iii) & (iv) \\
\cline { 2 - 5 } & $3.17^{\mathrm{a}}$ & $2.79^{\mathrm{a}}$ & $2.18^{\mathrm{a}}$ & $2.12^{\mathrm{b}}$ \\
LP size & $(5.68)$ & $(5.04)$ & $(3.63)$ & $(2.29)$ \\
& $2.48^{\mathrm{a}}$ & $3.02^{\mathrm{a}}$ & $3.41^{\mathrm{b}}$ & $3.40^{\mathrm{b}}$ \\
LP size squared & $(13.15)$ & $(4.40)$ & $(2.54)$ & $(2.46)$ \\
& & -0.02 & -0.11 & -0.10 \\
Number of PE funds & & $(-0.90)$ & $(-0.65)$ & $(-0.65)$ \\
& & & 0.01 & 0.01 \\
Number of PE funds squared & & & $(0.34)$ & $(0.23)$ \\
& & & & 0.00 \\
R-square & & & & $(-0.08)$ \\
Number of observations & 59.4 & 59.8 & 28.8 & 28.8 \\
\hline
\end{tabular}


Table 9: LP size, number of employees and scope of activities - Quintile analysis

This table shows statistics on the number of employee and scope of activities based on LP size quintiles. Variables are defined in section 2.2; LP size is measured in in US dollars million. 'Scope of activities' is the scaled investor activity score measure defined in section 4.5.

\begin{tabular}{|c|c|c|c|c|c|c|c|}
\hline \multicolumn{3}{|c|}{ LP size } & \multirow{2}{*}{$\begin{array}{l}\text { Number of LPs } \\
\text { in the quintile }\end{array}$} & \multicolumn{3}{|c|}{ Mean } & \multirow[b]{2}{*}{$\begin{array}{c}\text { PE professionals } \\
\text { per PE fund }\end{array}$} \\
\hline $\begin{array}{l}\text { Minimum } \\
\text { (excluded) }\end{array}$ & $\begin{array}{l}\text { Maximum } \\
\text { (included) }\end{array}$ & Mean & & $\begin{array}{c}\text { Number of } \\
\text { PE professionals }\end{array}$ & $\begin{array}{l}\text { Number of } \\
\text { PE funds }\end{array}$ & $\begin{array}{l}\text { Scope of } \\
\text { activities }\end{array}$ & \\
\hline 0.0 & 74.8 & 35.0 & 25 & 1.22 & 11.88 & 0.39 & 0.11 \\
\hline 74.8 & 227.1 & 146.5 & 26 & 2.76 & 20.42 & 0.46 & 0.15 \\
\hline 227.1 & 459.0 & 347.6 & 25 & 3.54 & 24.28 & 0.57 & 0.13 \\
\hline 459.0 & 1020.0 & 704.6 & 26 & 8.53 & 52.23 & 0.57 & 0.07 \\
\hline 1020.0 & 11087.9 & 3354.1 & 25 & 13.50 & 90.24 & 0.75 & 0.12 \\
\hline
\end{tabular}




\section{Table 10: Fund selection criteria}

This table reports results from Tobit regressions. Dependent variables are standardized score of investor selection criteria; scores range on a Likert scale from zero (the criterion is irrelevant) to five (the criterion is crucial). The standardization consists in subtracting the average answer of an investor across all of the questions and dividing by the standard deviation (i.e. building a z-score for each question and each investor). The explanatory variables are defined in sections 2.2 and 3.1. A constant is included but not shown. $t$-statistics are shown in italics between parenthesis. Significance levels in regressions are indicated by a $(1 \%), \mathrm{b}(5 \%)$, and c $(10 \%)$.

\begin{tabular}{|c|c|c|c|c|c|}
\hline & $\begin{array}{l}\text { (i) } \\
\text { Commitments } \\
\text { of other LPs }\end{array}$ & $\begin{array}{l}\text { (ii) } \\
\text { Advisor or gatekeeper } \\
\text { opinion }\end{array}$ & $\begin{array}{c}\text { (iii) } \\
\text { Multiple } \\
\text { previous funds }\end{array}$ & $\begin{array}{l}\text { (iv) } \\
\text { Fund size }\end{array}$ & $\begin{array}{c}(\mathrm{v}) \\
\text { Valuation } \\
\text { unrealized investments }\end{array}$ \\
\hline LP size $(\log )$ & $\begin{array}{l}-0.16^{\mathrm{a}} \\
(-2.95)\end{array}$ & $\begin{array}{l}-0.10^{\mathrm{a}} \\
(-2.61)\end{array}$ & $\begin{array}{c}0.16^{\mathrm{a}} \\
(4.76)\end{array}$ & $\begin{array}{l}0.15^{\mathrm{a}} \\
(3.51)\end{array}$ & $\begin{array}{c}0.08^{\mathrm{b}} \\
(2.42)\end{array}$ \\
\hline Corporate pension funds & $\begin{array}{c}-0.23 \\
(-0.81)\end{array}$ & $\begin{array}{c}0.00 \\
(-0.00)\end{array}$ & $\begin{array}{c}0.07 \\
(0.28)\end{array}$ & $\begin{array}{c}0.29 \\
(0.85)\end{array}$ & $\begin{array}{c}-0.02 \\
(-0.11)\end{array}$ \\
\hline Endowments & $\begin{array}{c}-0.22 \\
(-0.80)\end{array}$ & $\begin{array}{c}-0.14 \\
(-0.70)\end{array}$ & $\begin{array}{l}0.40^{\mathrm{b}} \\
(1.96)\end{array}$ & $\begin{array}{l}0.40^{\mathrm{c}} \\
(1.78)\end{array}$ & $\begin{array}{c}-0.23 \\
(-1.37)\end{array}$ \\
\hline Insurance companies & $\begin{array}{c}-0.35 \\
(-1.28)\end{array}$ & $\begin{array}{c}0.18 \\
(0.85)\end{array}$ & $\begin{array}{c}0.26 \\
(1.33)\end{array}$ & $\begin{array}{c}0.39 \\
(1.60)\end{array}$ & $\begin{array}{c}0.22 \\
(1.40)\end{array}$ \\
\hline Banks/Finance companies & $\begin{array}{l}-0.41^{b} \\
(-2.02)\end{array}$ & $\begin{array}{c}0.08 \\
(0.39)\end{array}$ & $\begin{array}{c}0.10 \\
(0.61)\end{array}$ & $\begin{array}{c}0.32 \\
(1.44)\end{array}$ & $\begin{array}{c}-0.02 \\
(-0.15)\end{array}$ \\
\hline Other LP types & $\begin{array}{c}-0.05 \\
(-0.22)\end{array}$ & $\begin{array}{c}-0.04 \\
(-0.23)\end{array}$ & $\begin{array}{l}0.35^{\mathrm{b}} \\
(2.20)\end{array}$ & $\begin{array}{c}0.27 \\
(1.27)\end{array}$ & $\begin{array}{c}-0.13 \\
(-0.77)\end{array}$ \\
\hline North America & $\begin{array}{c}0.31 \\
(1.44)\end{array}$ & $\begin{array}{c}-0.07 \\
(-0.48)\end{array}$ & $\begin{array}{c}0.02 \\
(0.12)\end{array}$ & $\begin{array}{c}0.07 \\
(0.40)\end{array}$ & $\begin{array}{c}-0.01 \\
(-0.06)\end{array}$ \\
\hline Continental Europe & $\begin{array}{c}-0.08 \\
(-0.53)\end{array}$ & $\begin{array}{c}0.27 \\
(1.55)\end{array}$ & $\begin{array}{c}-0.19 \\
(-1.44)\end{array}$ & $\begin{array}{l}-0.41^{b} \\
(-2.23)\end{array}$ & $\begin{array}{c}0.16 \\
(1.12)\end{array}$ \\
\hline LP experience (log) & $\begin{array}{c}-0.08 \\
(-0.57)\end{array}$ & $\begin{array}{c}0.08 \\
(0.80)\end{array}$ & $\begin{array}{l}-0.19^{a} \\
(-2.60)\end{array}$ & $\begin{array}{c}0.04 \\
(0.36)\end{array}$ & $\begin{array}{c}-0.02 \\
(-0.28)\end{array}$ \\
\hline Parent experience $(\log )$ & $\begin{array}{c}0.07 \\
(0.88)\end{array}$ & $\begin{array}{c}0.02 \\
(0.40)\end{array}$ & $\begin{array}{c}-0.03 \\
(-0.51)\end{array}$ & $\begin{array}{c}-0.01 \\
(-0.22)\end{array}$ & $\begin{array}{l}-0.10^{b} \\
(-2.03)\end{array}$ \\
\hline (OLS) R-square & 14.95 & 8.31 & 15.00 & 13.60 & 14.95 \\
\hline Number of observations & 153.0 & 153.0 & 153.0 & 137.0 & 137.0 \\
\hline \multicolumn{6}{|c|}{ Mean value of the dependent variable for: } \\
\hline Small LPs & -0.41 & -0.29 & -0.37 & -0.39 & -0.22 \\
\hline Large LPs & -1.08 & -0.65 & 0.11 & 0.18 & 0.21 \\
\hline
\end{tabular}


Figure 1: Histogram of the investor scope of activities

The figure reports the histogram for the scaled investor scope of activity score variable defined in section 4.5.

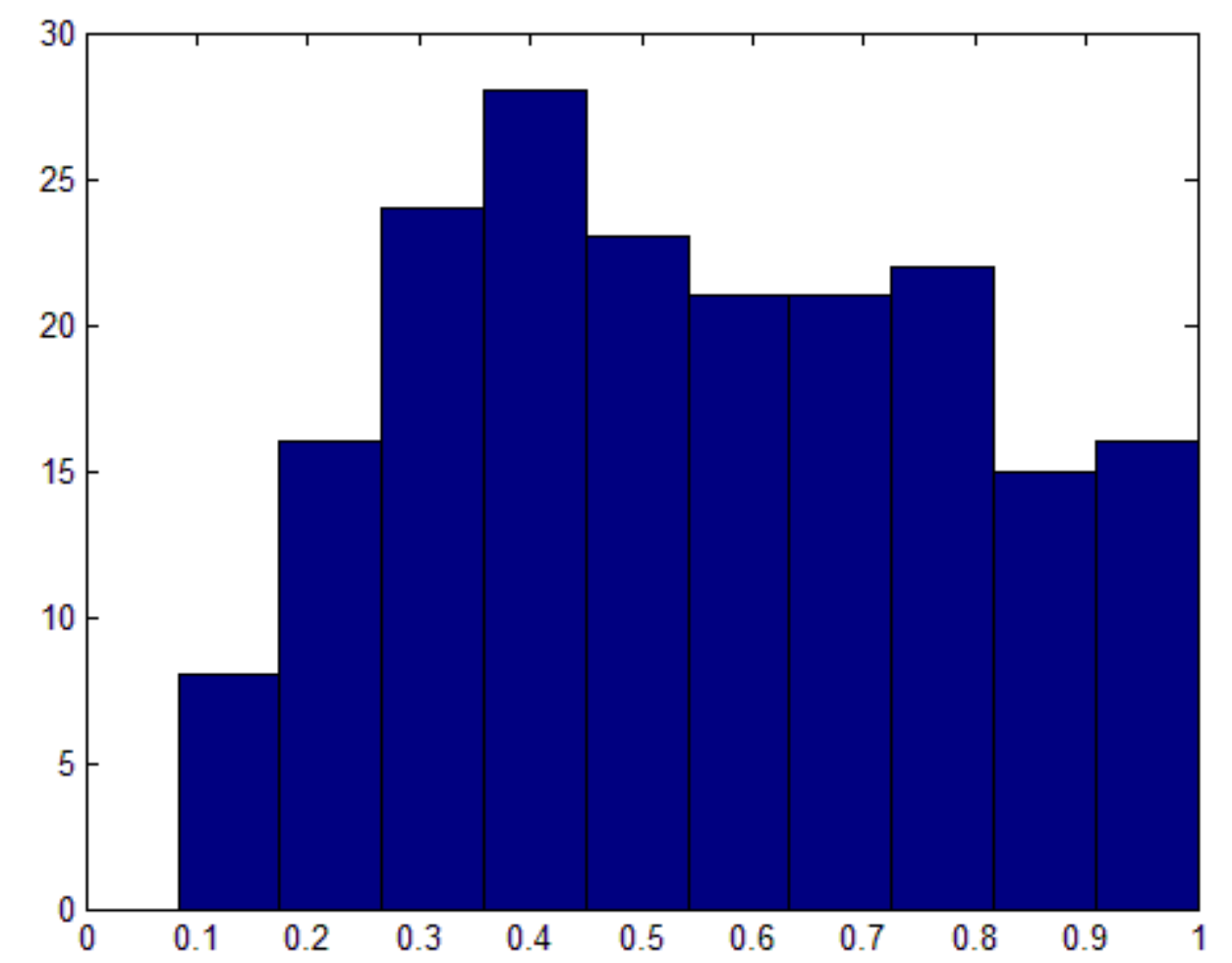

